\title{
ETNOPEDAGOGI DALAM PEMBELAJARAN DI SEKOLAH DASAR MELALUI MEDIA BERBASIS KEARIFAN LOKAL
}

\author{
Ika Oktavianti ${ }^{1 \bowtie}$, dan Yuni Ratnasari ${ }^{2}$
}

Prodi Pendidikan Guru Sekolah Dasar Fakultas Keguruan dan Ilmu Pendidikan Universitas Muria Kudus

\section{Info Artikel Abstract}

Sejarah Artikel:

Diterima 11 Des 2017

Direvisi 13 Mar 2018

Dipublikasikan Jun 2018

\section{Keywords:}

Etnopedagogi, Media

Based on Local Wisdom
Etnopedagogi is the actualization of the learning-oriented cultivation of the values of local wisdom. A an approach, etnopedagogi in elementary school need to be implemented with innovative learning strategies as well as media that are able to attract the attention of the students to understand and apply the local wisdom. This research uses mixed methods with concurrent triangulation strategy. The results showed that etnopedagogi as a learning approach is implemented through the activities of learningbased media that presents the local wisdom is more effective. In the use of media-based local advantages often accompanied by various activities of play, thus creating an active learning, creative, effective, and fun. This shows that etnopedagogi successfully applied on learning in elementary school if the implementation of innovative learning activities presented with such media-based local wisdom.

\begin{abstract}
Abstrak
Etnopedagogi merupakan aktualisasi pembelajaran yang berorientasi pada penanaman nilai-nilai kearifan lokal. Sebagai pendekatan, etnopedagogi di sekolah dasar perlu diimplementasikan dengan strategi maupun media pembelajaran inovatif yang mampu menarik perhatian siswa untuk memahami dan mengaplikasikan kearifan lokal. Penelitian ini menggunakan mixed methods dengan strategi triangulasi konkuren. Hasil penelitian menunjukkan bahwa etnopedagogi sebagai pendekatan pembelajaran yang diimplementasikan melalui kegiatan pembelajaran yang menyajikan media berbasis kearifan lokal lebih efektif. Dalam penggunaan media berbasis keunggulan lokal seringkali diiringi dengan berbagai aktivitas bermain, sehingga menciptakan pembelajaran yang aktif, kreatif, efektif, dan menyenangkan. Hal ini menunjukkan bahwa etnopedagogi berhasil diaplikasikan pada pembelajaran di sekolah dasar jika pelaksanaan disajikan dengan kegiatan pembelajaran inovatif seperti media berbasis kearifan lokal
\end{abstract}

(C) 2018 Universitas Muria Kudus
p-ISSN 2087-9385 e-ISSN 2528-696X

\author{
Program Studi Pendidikan Guru Sekolah Dasar \\ Fakultas Keguruan dan Ilmu Pendidikan Universitas Muria Kudus \\ Kampus UMK Gondangmanis, Bae Kudus Gd. L. 1t I PO. BOX 53 \\ Kudus \\ Tlp (0291) 438229 ex.147 Fax. (0291) 437198 \\ E-mail: ika.oktavianti@umk.ac.id
}




\section{PENDAHULUAN}

Kurikulum pendidikan di Indonesia meskipun telah mengalami beberapa kali perubahan kurikulum, pembelajaran diharapkan memuat konten etnopedagogi dimana kegiatan pembelajaran diharuskan menekankan kearifan lokal peserta didik. Kearifan lokal menurut Zulkarnain dan Febriamansyah (2008: 72) merupakan prinsip-prinsip dan cara-cara tertentu yang dianut, dipahami, dan diaplikasikan oleh masyarakat lokal dalam berinteraksi dan berinterelasi dengan lingkungannya dan ditransformasikan dalam bentuk sistem nilai dan norma adat.

Etnopedagogi pada kurikulum 2013 dilandaskan pada Peraturan Menteri Pendidikan dan Kebudayaan Republik Indonesia Nomor 79 Tahun 2014 menjelaskan bahwa pembelajaran baik ditingkat sekolah dasar/madrasah ibtidaiyah sampai pada sekolah menengah atas/sekolah menengah kejuruan harus bermuatan lokal yang merupakan bahan kajian atau mata pelajaran pada satuan pendidikan yang berisi muatan dan proses pembelajaran tentang potensi dan keunikan lokal yang dimaksudkan untuk membentuk pemahaman peserta didik terhadap keunggulan dan kearifan di daerah tempat tinggalnya.

Tilaar (2015: 24) menjelaskan bahwa kearifan lokal mempunyai nilai pedagogis untuk mengatur tingkah laku yang bermanfaat bagi kepentingan bersama masyarakat. Kajian ini sesuai dengan Peraturan Menteri Pendidikan dan Kebudayaan Republik Indonesia Nomor 79 Tahun 2014 pasal 2 ayat (2) menjelaskan bahwa muatan lokal diajarkan dengan tujuan membekali peserta didik dengan sikap, pengetahuan, dan spiritual di daerahnya. Tujuan lainnya yaitu melestarikan dan mengembangkan keunggulan dan kearifan daerah yang berguna bagi diri dan lingkungannya dalam rangka menunjang pembangunan nasional.

Pembelajaran yang berorientasi etnopedagogi sangat penting diterapkan mengingat Indonesia merupakan negara majemuk yang terdiri dari berbagai suku bangsa dan etnis yang tentunya memiliki budaya yang berbeda-beda. Kedua, globalisasi dan perkembangan teknologi dapat menyebabkan perubahan budaya pada masyarakat Indonesia.

Jika pembelajaran berorientasi pada etnopedagogi tidak diterapkan sejak dini, maka masa yang akan datang globalisasi dan perkembangan teknologi yang sangat pesat dapat menggeser kearifan lokal dalam masyarakat. Pergeseran ini terjadi karena tidak adanya batasan yang jelas antara budaya lokal dan budaya asing. Kondisi ini jelas menunjukkan bahwa pendidikan di Indonesia perlu menerapkan pembelajaran yang berorientasi pada kearifan lokal.

Sularso (2016:74) menyebutkan bahwa proses pendidikan dengan menjadikan kearifan lokal penting untuk direalisasikan sebab kearifan lokal sudah mulai terabaikan yang terlihat dari perilaku kehidupan sehari-hari yang tidak mewujdukan nilai-nilai kearifan lokal dan lokalitas tergerus oleh tatanan gaya hidup yang di dalamnya mengandung nilai pragmatiskapitalistik. Sementara itu, Syaifulloh dan Wibowo (2017) menyatakan Syair Gulung sebagai kearifan lokal masyarakat Melayu Kabupaten Ketapang Kalimantan Barat memiliki nilai pendidikan kebencanaan.

Permasalahannya yang masih muncul, penyelenggaraan pembelajaran berorientasi pada kearifan lokal belum berjalan optimal. Ridwan (2014: 102) menjelaskan bahwa selama ini pendidikan dan nilai kearifan lokal belum sepenuhnya melebur menjadi satu kekuatan baru yang tangguh di tubuh pendidikan Indonesia.

Di sekolah dasar, pembelajaran yang berorientasi kearifan lokal belum diterapkan secara optimal meskipun sudah diterapkannya pembelajaran tematik yang dalam pengajarannya harus memuat kearifan lokal. Temuan di lapangan, kurang optimalnya pembelajaran berorientasi kearifan lokal disebabkan karena tidak mendukungnya sarana dan prasarana. Oleh sebab itu, kajian ini membahas tentang media pembelajaran berbasis kearifan lokal sebagai sarana dan prasarana yang mendukung implementasi pembelajaran berbasis kearifan lokal khususnya di sekolah dasar.

\section{METODE PENELITIAN}

Penelitian ini menggunakan pendekatan penelitian metode campuran. Rachman (2015: 241) menjelaskan penelitian metode campuran merupakan pendekatan penelitian yang mengkombinasikan atau mengasosiasikan bentuk kualitatif dan kuantitatif. Strategi penelitian metode campuran yang digunakan dalam penelitian ini ialah Strategi Triangulasi Konkuren. Peneliti menerapkan strategi ini dengan tujuan untuk menghasilkan penemuan yang substantif dan tervalidasi.

Pengumpulan data dilakukan dengan menggunakan teknik observasi, tes, dokumentasi, dan catatan lapangan. Metode observasi yang diterapkan dalam penelitian ini adalah observasi partisipatif. Pada observasi partisipasif ini peneliti juga menggunakan rating 
scale pada penskoran tiap indikator yang diamati. Sugiyono (2010: 97) mengemukakan, rating scale ialah data mentah yang diperoleh berupa angka kemudian ditafsirkan dalam pengertian kualitatif.

Metode tes pada penelitian ini diberikan kepada seseorang dengan maksud untuk mendapatkan seberapa besar kemampuan peserta didik pada pengembangan pemahaman konsep muatan pembelajaran yang ditematikkan menggunakan konten kearifan lokal. Tes yang dilakukan berbentuk tes formatif dengan tujuan untuk mengetahui peningkatan kecerdasan multiple intelligences peserta didik.

Dokumentasi pada penelitian ini diterapkan mempelajari membaca dan mencatat apa yang tersirat dan tersurat dalam dokumen, laporan peraturan dan literatur lainya yang relevan dengan peneliti, seperti daftar nama siswa yang akan diperlukan dalam penelitian ini, literatur yang berkaitan dengan pembelajaran tematik dan kearifan lokal. Catatan lapangan digunakan untuk mencatat termuan-temuan selama di lapangan, sehingga dapat memperkuat data penelitian.

Teknik analisis data menggunakan analisis data kuantitatif dan data kualitatif dengan tujuan kuantifikasi data kualitatif agar dapat dianaliasis secara kuantitatif dimana data kuantitatif didasarkan pada asumsi dan penilaian yang dinyatakan dengan data kuantitatif. Analisis data kuantitatif menggunakan teknik analisis statistik deskriptif sedangkan analisis data kualitatif menggunakan model analisis interaktif.

\section{HASIL DAN PEMBAHASAN}

Etnopedagogi merupakan cerminan muatan lokal pada pembelajaran atau lebih dikenal dengan pembelajaran berbasis kearifan lokal. Utari, Degeng dan Akbar (2016: 42) secara umum, kearifan lokal memiliki ciri dan fungsi yaitu 1) sebagai penanda identitas sebuah komunitas, 2) sebagai elemen perekat kohesi sosial, (3) sebagai unsur budaya yang tumbuh dari bawah, eksis dan berkembang dalam masyarakat, bukan merupakan sebuah unsur yang diapksakan dari atas, 4) berfungsi memberikan warna kebersamaan bagi komunitas tertentu, 5) dapat mengubah pola pikir dan hubungan timbal balik individu dan kelompok dengan meletakkannya di atas common ground, 6) mampu mendorong terbangunnya kebersamaan, apresiasi dan mekanisme bersama untuk mempertahankan diri dari kemungkinan terjadinya gangguan atau perusak solidaritas kelompok sebagai komunitas yang utuh dan terintegrasi.

Kearifan lokal yang dikembangkan pada pembelajaran menggunakan prinsip empat prinsip yaitu 1) kesesuaian dengan perkembangan peserta didik, 2) kebutuhan kompetensi, 3) flekstibilitas jenis, bentuk, dan pengaturan waktu penyelenggaraan, dan 4) kebermanfaatan untuk kepentingan nasional menghadapi tantangan global.

Penelitian ini mengusung ke empat prinsip tersebut pada pembelajaran tematik kurikulum 2013 dengan menggunakan media pembelajaran yang berupa permainan. Konsep pembelajaran tematik pada penelitian ini disesuaikan dengan Peraturan Menteri Pendidikan dan Kebudayaan Republik Indonesia Nomor Nomor 65 Tahun 2013 tentang standar proses pembelajaran yang mengimplementasikan pembelajaran tematik terpadu bagi pendidikan sekolah dasar/madrasah ibtidaiyah.

Etnopedagogi yang tercermin pada kearifan lokal diterapkan pada penelitian ini dimaksudkan untuk memperkenalkan dan melestarkan budaya lokal pada peserta didik sehingga diharapkan peserta didik memahami dan semakin mencintai kearifan lokalnya. Harapan ini disesuaikan dengan kajian Sartini (2010: 19) yang menyebutkan bahwa kearifan lokal merupakan gagasan setempat (lokal) yang bersifat bijaksana, penuh kearifan, bernilai baik yang tertanam dan diikuti oleh anggota masyarakat. Kajian kearifan lokal perlu ditanamkan sejak dini agar peserta didik mampu menghadapi tantangan global.

Untuk mewujudkan harapan tersebut, kajian pembelajaran harus mengaitkan materi nilai-nilai kearifan lokal peserta. Ridwan (2014: 102) menjelaskan bahwa kurikulum 2013 dan nilai kearifan kearifan lokal harus menjadi semangat penyempurna dan menjadikannya sesuatu hal niscaya bagi kepanjangan napas pendidikan di Indonesia, sebagai penciptaan kekuatan masa depan pendidikan yang arif dan berkeadaban.

Konsep kearifan lokal yang diusung pada penelitian ini dikaitkan dengan kearifan lokal Kabupaten Pati yang mencakup kajian kebudayaan menurut Koentjaraningrat (1974: 12) yaitu sistem religi, kemasyarakatan, pengetahuan, bahasa, kesenian, mata pencaharian, sistem teknologi dan peralatan.

Kabupaten Pati merupakan bagian provinsi Jawa Tengah yang banyak dikenal masyarakat Indonesia karena religi kejawennya dan makanan khas yaitu nasi gandul dan 
bandeng presto, serta kerajinan kuningan Juwana. Kearifan lokal inilah yang patut dilestarikan dan diturun dari generasi ke generasi. Dalam hal ini, peran pendidikan dirasakan penting untuk mengenalkan sejak dini kepada peserta didik akan kearifan lokal daerahnya. Guru sebagai fasilitator utama dalam pendidikan.

Hasil penelitian tersebut menjadi rujukan untuk mengembangkan media pembelajaran yang berbasis kearifan lokal. Tujuan pengembangan media ini sesuai dengan goal lesson desain yang dicapai ialah siswa bangga dengan local wisdom Pati.

Goal learning desain tersebut ditentukan berdasarkan kompetensi dasar pembelajaran tematik kurikulum 2013 (pengetahuan) yang disajikan pada tabel berikut.

Tabel 1. Kompetensi Dasar Tematik kelas IV Sekolah Dasar/Madrasah Ibtidaiyah

\begin{tabular}{|c|c|c|}
\hline Muatan & Pengetahuan & Keterampilan \\
\hline PPkn & $\begin{array}{l}\text { 3.4mendeskripsikan } \\
\text { berbagai bentuk } \\
\text { keberagaman suku } \\
\text { bangsa, sosial, dan } \\
\text { budaya di Indonesia } \\
\text { yang terikat } \\
\text { persatuan } \\
\text { kesatuan }\end{array}$ & $\begin{array}{l}4.4 \text { bekerja sama } \\
\text { dalam } \\
\text { keberagaman suku } \\
\text { bangsa, sosial, dan } \\
\text { budaya dalam } \\
\text { masyarakat }\end{array}$ \\
\hline Bahasa & 3.1 Mencermati & 4.1 Menata \\
\hline Indonesia & $\begin{array}{l}\text { gagasan pokok dan } \\
\text { gagasan pendukung } \\
\text { yang diperoleh dari } \\
\text { teks lisan, tulis, atau } \\
\text { visual }\end{array}$ & $\begin{array}{l}\text { informasi yang di } \\
\text { dapat dari teks } \\
\text { berdasar } \\
\text { keterhubungan } \\
\text { antar gagasan ke } \\
\text { dalam kerangka } \\
\text { tulis }\end{array}$ \\
\hline Matematika & $\begin{array}{l}3.9 \text { menjelaskan dan } \\
\text { menentukan keliling } \\
\text { dan luas daerah } \\
\text { persegi, } \\
\text { persegipanjang, dan } \\
\text { segitiga }\end{array}$ & $\begin{array}{l}4.9 \text { menyelesaikan } \\
\text { masalah berkaitan } \\
\text { dengan keliling } \\
\text { dan luas daerah } \\
\text { persegi, } \\
\text { persegipanjang, } \\
\text { dan segitiga }\end{array}$ \\
\hline IPA & $\begin{array}{l}3.8 \text { memahami } \\
\text { pentingnya upaya } \\
\text { keseimbangan dan } \\
\text { pelestarian sumber } \\
\text { daya alam di } \\
\text { lingkungannya }\end{array}$ & $\begin{array}{l}4.8 \text { melakukan } \\
\text { kegiatan upaya } \\
\text { pelestarian sumber } \\
\text { daya alam bersama } \\
\text { orang-orang di } \\
\text { lingkungannya }\end{array}$ \\
\hline IPS & $\begin{array}{l}3.3 \text { mengidentifikasi } \\
\text { kegiatan ekonomi } \\
\text { dalam meningkatkan } \\
\text { kehidupan } \\
\text { masyarakat di } \\
\text { bidang pekerjaan, } \\
\text { sosial, dan budaya di } \\
\text { lingkungan sekitar } \\
\text { sampai dengan } \\
\text { provinsi }\end{array}$ & $\begin{array}{l}4.3 \text { menyajikan } \\
\text { hasil identifikasi } \\
\text { kegiatan ekonomi } \\
\text { dalam } \\
\text { meningkatkan } \\
\text { kehidupan } \\
\text { masyarakat di } \\
\text { bidang pekerjaan, } \\
\text { sosial, dan budaya } \\
\text { di lingkungan } \\
\text { sekitar sampai } \\
\text { dengan provinsi }\end{array}$ \\
\hline
\end{tabular}

Sumber: Oktavianti dan Ratnasari (2017a: 3538)
Berdasarkan kompetensi dasar tersebut, media pembelajaran berbasis kearifan lokal tersebut berupa monopoli engklek berbantu billboard rangking atau disingkat dengan MONEK BILLKING. Komponen yang terdapat pada permainan tersebut ialah media permainan monopoli engklek jelajah Kabupaten Pati, dadu, kartu kesempatan, kartu umum, kartu budaya, metrik ingatan, dan whiteboard slides.

Langkah-langkah MONEK BILLKING seperti yang dijelaskan Oktavianti dan Ratnasari (2017b: 68-69) yaitu buatlah kelompok (jumlah anggota menyesuaikan, jika anggota kelas berjumlah 20 orang, maka 1 kelompok terdiri dari 5 anggota kelompok). Kemudian berikan nama kelompok tersebut. Langkah kedua, bagi kartu hak milik pada setiap kelompok dengan warna yang berbeda pada setiap kelompok. Guru juga membagikan matrik ingatan pada setiap kelompok.

Langkah ketiga, siswa mengocok dadu secara bergiliran (semua anggota kelompok secara bergiliran menjadi pin perwakilan kelompoknya), angka yang terbanyak dapat bermain dahulu. Permainan dimulai dari petak "Go" dan dilanjutkan dengan secara bergiliran, siswa mengocok dadu dan melemparkannya kemudian pemain melompat beberapa kali sesuai jumlah angka dadu yang keluar. Jika permain berada di posisi petak budaya yang belum di miliki oleh kelompok lain, maka petak tersebut menjadi hak milik (guru memberikan Kartu Hak Milik pada kelompok tersebut). Siswa juga harus membacakan dengan suara yang lantang Kartu Budaya pada petak tersebut. Para siswa lain di setiap anggota mendengarkan dan mencatat pada matrik ingatan.

Peraturan pada permainan ini, jika siswa berada pada petak budaya yang sudah dimiliki kelompok lain maka mereka berhak hukuman. Apabila siswa berhenti "Visiting Jail" maka siswa harus berhenti (tidak boleh bermain) namun masih bisa digantikan anggota lainnya pada kelompok tersebut.

Apabila siswa berhenti di kesempatan atau dana umum siswa, siswa mengambil kartu teratas. Kartu Kesempatan berisi tentang pembebasan hukuman apabila seorang siswa berhenti di petak budaya yang dimiliki kelompok lain atau bebas dari penjara, sedangkan Kartu Dana berisi tentang kepemilikan bersama petak budaya bersama kelompok lain.

Langkah keempat, permainan berhenti saat semua petak budaya sudah dimiliki semua. Kelompok dengan kepemilikan Kartu Budaya menjadi pemenang dalam permainan ini. 
Langkah kelima, setiap siswa kembali ke tempat duduk sesuai dengan masing-masing kelompok, kemudian guru meminta setiap kelompok untuk melengkapi konsep pembelajaran tematik yang tersimpan di Kartu Budaya yang telah dibacakan setiap siswa yang telah dicatat pada matrik ingatan.

Langkah keenam yaitu setelah semua kelompok melengkapi matrik, guru mengarahkan siswa kepada penemuan konsep materi melalui billboard rangking. Pada penelitian yang dilakukan penulis, guru memilih budaya religi tentang ziarah makam Saridin yang dikaitkan dengan muatan yang disajikan dalam pembelajaran tematik sesuai dengan kompetensi dasar. Setiap kelompok diminta untuk mempresentasikan hasil temuannya.

Langkah ketujuh yang dilakukan ialah guru memberikan penghargaan kepada kelompok dengan penemuan konsep tercepat dan tentunya disertai pula dengan akurat hasil temuannya. Langkah terakhir ialah guru meminta siswa untuk menuliskan pengalaman, cita-cita, dan kesan terhadap pembelajaran yang telah dilakukan dengan menggunakan media permainan MONEK BILLKING.

Hasil penerapan media permainan monek billking pada siswa kelas IV di SD Sukoharjo 01 dan SD Widorokandang 01 menunjukkan bahwa goal learning desain pembelajaran tematik terpadu menggunakan MONEK BILLKING Kearifan Budaya Pati menunjukkan yaitu siswa bangga dengan kearifan budaya Pati mencapai keberhasilan.

Kesan yang diberikan kepada siswa pada pembelajaran menggunakan media permainan MONEK BILLKING pada pembelajaran tematik menunjukkan bahwa selama pelaksanaan pembelajaran, mereka tidak merasakan belajar tetapi bermain. Meskipun yang dirasakan bermain, ketika guru memberikan follow up berupa kegiatan refleksi akhir pembelajaran, siswa mampu menjawab dengan tepat meskipun konsep materi telah dioleh oleh guru.

Melalui ungkapan-ungkapan yang disampaikan siswa kepada guru sebelum mengakhiri pembelajaran, siswa berharap setiap hari mendapatkan kegiatan belajar diwarnai dengan bermain. Hal ini menunjukkan bahwa selama proses pembelajaran siswa tidak mengalami tekanan belajar, dan joyfull learning benar-benar dirasakan oleh mereka. Kajian ini menunjukkan bahwa jika guru sebagai fasilitator utama pada pembelajaran mampu menggunakan atau menerapkan pembelajaran yang inovatif, maka permasalah kejenuhan belajar yang banyak dialami siswa selama ini dapat diatasi.

\section{SIMPULAN}

Kajian yang menarik dari penelitian yang mengusung etnopedagogi ini ialah pada pembelajaran tematik menggunakan media permainan MONEK BILLKING, selain siswa mengenal kearifan lokal di sekitar siswa, siswa memahami muatan materi yang disajikan pada pembelajaran tematik menggunakan konten kearifan lokal, siswa juga menemukan cita-cita di masa yang akan datang terkait dengan jenis pekerjaan yang dituju. Ada yang menyatakan menjadi polisi, guru, nelayan, pengusaha, dan bahkan yang lebih mengejutkan terdapat siswa yang ingin menjadi pengusaha kuningan dan menjadi pembatik. Hal ini menunjukkan bahwa siswa merasa bangga dengan kearifan lokal Pati dan sebagai perwujudan siswa dalam melestarikan kearifan lokal daerah tempat tinggalnya.

\section{DAFTAR PUSTAKA}

Oktavianti, I. Y. Ratnasari. 2017a. Peningkatan Multiple Intelligences Siswa Pada Pembelajaran Temaik Melalui Lesson Study Berbantu Monek Billking Kearifan Budaya Pati. Laporan Penelitian Dosen Pemula. Kudus: Universitas Muria Kudus.

2017b. Permainan Monopoli Engklek Budaya Pati Untuk Pembelajaran Tematik. Prosiding Seminar Nasional, Pendidikan Bahasa dan Sastra Indonesia Universitas Muria Kudus Tahun 2017, 63-71.

Rachman, M. 2015. 5 Pendekatan Penelitian: Kuantitatif, Kualitatif, Mixed, PTK dan $R \& D$. Yogyakarta: Magnum Pustaka Utama.

Ratnasari, Y. Santoso. 2015. Pengembangan Media Pembelajaran Tematik Integratif Dengan Pendekatan Scientifik berbasis Budaya Lokal Masyarakat Kabupaten Pati. Prosiding Seminar Nasional Kebangkitan Teknologi, Universitas Muria Kudus Tahun 2015, 35-40.

Ridwan, M. 2014. Kurikulum 2013 dan Pendidikan Nilai Kearifan Lokal di Sekolah Dasar. Prosiding Seminar Nasional Pendidikan tema Implementasi 
Kurikulum 2013 dan Problematikanya, Pascasarjana UNESA Tahun 2014, 102108.

Sartini. 2010. Menggali Kearifan Lokal Nusantara: Sebuah Kajian Filsafat. Jurnal Filsafat, 14 (2): 111-120.

Sugiono. 2010. Metode Penelitian Pendidikan. Bandung: Alfabeta.

Sularso. 2016. Revitalisasi Kearifan Lokal Dalam Pendidikan Dasar. Jurnal Pendidikan Sekolah Dasar, 2 (1): 73-79.

Tilaar, H.A.R. 2015. Pedagogik Teoritis untuk Indonesia. Jakarta: Buku Kompas.
Utari, Unga. Dkk. 2016. Pembelajaran Tematik Berbasis Kearifan Lokal di Sekolah Dasar Dalam Menghadapi Masyarakat ekonomi ASEAN (MEA). Jurnal Teori dan Praksis Pembelajaran IPS. , 1 (1): 39-44.

Syaifulloh, Muhammad., dan Wibowo, Basuki. 2017. Nilai-Nilai Edukatif Syair Gulung Sebagai Upaya Pendidikan Kebencanaan Berbasis Komunitas Pada Masyarakat Melayu Di Kabupaten Ketapang Kalimantan Barat. Jurnal Refleksi Edukatika, 8 (1): 48-53.

Zulkarnain, A. Febriamansyah, R. 2008. Kearifan Lokal dan Pemanfaatan dan Pesisir. Jurnal Agribisnis Kerakyatan, 1 (1): 69-84. 